\title{
FIRST INVESTIGATION OF THE COMPOSITION AND SPATIAL DISTRIBUTION OF POLYCHAETE FEEDING GUILDS FROM ESSAOUIRA PROTECTED COASTAL AREA (ATLANTIC COAST OF MOROCCO)
}

\author{
Chouikh, N. ${ }^{1}$ - Gillet, P. $^{2}$ - LAngston, W. J. ${ }^{3}$ - Cheggour, M. ${ }^{4}-$ MAarouf, A. ${ }^{1}-$ \\ MOUABAD, A..$^{*}$ \\ ${ }^{1}$ Laboratory “Aliments, Environnement et Santé", Faculty of Sciences and Technics, Cadi \\ Ayyad University, B. P. 549, Marrakech, Morocco \\ ${ }^{2}$ Mer Molécules Santé, Department of Biology Environment, Faculty of Sciences, UCO \\ Angers, France \\ ${ }^{3}$ Marine Biological Association \\ The Laboratory, Citadel Hill, Plymouth PL1 2PB, United Kingdom \\ ${ }^{4}$ Department of Biology, Ecole Normale Supérieure, Cadi Ayyad University \\ B. P. 2400, Marrakech, Morocco \\ *Corresponding author \\ e-mail:a.mouabad@uca.ma \\ (Received 22 ${ }^{\text {nd }}$ Nov 2018; accepted $28^{\text {th }}$ Jan 2019)
}

\begin{abstract}
Several researches have been conducted to explain patterns of the abundance, richness and taxonomic diversity of benthic polychaetes; however, such analyses have ignored the functional diversity of polychaete communities, especially feeding guilds in intertidal rocky shores. The present study was carried out to describe and analyse the polychaete feeding guilds on intertidal rocky shores and then examine the effects of environmental factors. Twelve intertidal rocky shores from the coastal protected area of Essaouira (Atlantic coast of Morocco) were sampled during the summer of 2016. A total of 42 polychaete species belonging to 29 genera and 16 families were identified among the 4517 specimens collected. The medium biomass per sampling site was found to be $37.61 \pm 15.80 \mathrm{~g} . \mathrm{m}^{-2}$. The polychaete species were classified into five feeding guilds, and nine feeding modes. The filter feeders were the dominant feeding guild (32\%) followed by omnivores (23\%), burrowers (20\%), carnivorous (15\%) and surface deposit-feeders $(10 \%)$. The FDT (filter feeder, discretely motile, with tentacles) was the most abundant feeding mode, accounting for $24 \%$ of abundance (mainly represented by Sabellaria alveolata), followed by the ODJ feeding mode (omnivorous, discretely motile, with jaw apparatus) with $22 \%$, and the SDT feeding mode (surface deposit feeder, discretely motile, with tentacles) with $18.9 \%$. The highest trophic importance index and index of trophic diversity values were recorded in the southern region of Essaouira coastline. Based on the canonical correspondence analysis, composition and spatial distribution of polychaete feeding guilds were mainly related to the length of rocky shores and water temperature.
\end{abstract}

Keywords: rocky shores, intertidal, environmental factors, functional diversity, feeding modes, filter feeders, trophic importance index

\section{Introduction}

Polychaetes (Annelida) are one of the most important taxa in macrobenthic communities in coastal and marine environments, in terms of diversity and abundance (Fauchald and Jumars, 1979; Grassle and Maciolek, 1992; Hutchings, 1998). With more than 13,000 species described to date, polychaetes species are considered the most numerous among benthic taxa (Minelli, 1993; Jumars et al., 2015; Han et al., 2016). 
Indeed, the polychaetes represent about one third of the total macrobenthic species in terms of richness and up to $80 \%$ of the total abundance (Fauchald and Jumars, 1979; Belan, 2004; Manokaran et al., 2013; Han et al., 2016). They are also crucial in marine food chains as important prey and predators for many organisms (Serrano Samaniego, 2012), and exhibit a high diversity of feeding modes, reproductive strategies and different levels of tolerance to the negative impacts induced by pollution and natural perturbations (Giangrande et al., 2005; MacDonald et al., 2010; Sivadas et al., 2010; Han et al., 2016).

According to Fauchald and Jumars (1979), feeding guild of any organism is defined as the set of relations among food particle size and composition, the mechanism involved in food intake, and the motility patterns associated with feeding. These authors classified feeding guilds of each polychaete family as herbivore, carnivore, filter feeders, surface deposit feeders, and sub-surface deposit-feeders. Later, Ruppert and Barnes (1994) suggested that omnivores also exist in the marine environment. According to Pinnet (2000), organisms of the same feeding guild would dominate a particular type of substrate. Indeed, the filter-feeders are the dominant feeding guild on hard substrate (Porras et al., 1996; Damianidis and Chintiroglou, 2000), while depositfeeders are the dominant feeding guild on soft substrates (Paiva, 1994; Muniz and Pires, 1999; Mattos et al., 2012). Deposit feeders usually inhabit low-energy, muddy substrates because such substrates tend to have a high content of organic matter (Muniz and Pires, 1999; Wang, 2004; Méndez, 2013). By contrast, filter-feeders would not find enough suspended food in muddy substrates, but could be abundant on gravel and coarse-sand bottoms, since currents provide a continuous supply of suspended organic detritus and plankton (Wang, 2004).

Several biotic or abiotic factors can affect the composition and distribution patterns of polychaete feeding guilds. These include total organic carbon (Denisenko et al., 2003; Taurusman, 2010; Han et al., 2016), food availability (Dauwe et al., 1998; Rosenberg, 2001), depth and salinity (Rosenberg, 2001; Han et al., 2016). Physical characteristics of substrates and hydrodynamic factors may also modify distributions (Arruda et al., 2003; Sanders, 1958). Thus, feeding guilds can be used as a tool to analyse polychaete assemblage patterns, due to their dependence on the environmental variables, and studies on feeding guilds can permit ecologists to understand the ecological function of each species and predict if an ecosystem was susceptible to invasion by certain species (Fauchald and Jumars, 1979).

In Morocco, polychaetes represent an important group in terms of abundance and diversity on the continental shelf. The first attempt to explain patterns of abundance, richness and diversity of benthic polychaetes goes back to the beginning of $20^{\text {th }}$ century with Charrier (1921) who drew up the first list of polychaetes from the region of Tangier. Subsequently, many studies have been carried out on the polychaetes of Morocco, up to the recent description of Boccardia polybranchia as a new species along the rocky shores of Safi (Goumri et al., 2017). However, these analyses did not consider the overall functional structure of polychaete communities. Some studies examined polychaete feeding guilds in sandy beach environments, such as the investigations of macrofauna communities carried out on the Atlantic coast between Tangier and Tarfaya by Bayed (1991), in Bou Regreg estuary by Cherkaoui et al. (2003) and in Merja Zerga by Bazaïri et al. (2003) and Touhami et al. (2017). On the Mediterranean coast, the lagoon of Smir was also studied by Chaouti and Bayed (2011). However, analyses of polychaete feeding guilds on intertidal rocky shores are virtually absent. The aim of this 
paper was to describe, for the first time, the composition and spatial distribution patterns of polychaete feeding guilds in the intertidal rocky shores of Essaouira (Atlantic coast of Morocco), and their dependence to various environmental variables.

\section{Materials and methods}

\section{Study area}

The study area is located along the Atlantic coast of Essaouira province, Morocco. It lies between longitudes $9^{\circ} 20^{\prime}$ and $9^{\circ} 90^{\prime}$ 'West and between latitudes $31^{\circ} 10^{\prime}$ and $31^{\circ}$ $50^{\prime}$ North (Fig. 1). This coastal zone is made up of sandy beaches, rocky shores and dunes (fixed and shifting) with elevations ranging from 0 to $43 \mathrm{~m}$. The lithology is composed of quaternary conglomerate, colluvial, and alluvial deposits and Jurassic limestone (Molua Mwambo et al., 2007). The hydrographic network includes a few rivers. The main ones are oued Ksob, oued Tidzi and oued Aghbalou which are located in the south of Essaouira while oued Tahria is located in the north. The area climate is semi-arid with a long dry period that lasts from April to October. The aridity decreases from east to west. In the western narrow coastal fringe around the town of Essaouira, the influence of the cold currents that flow onshore from the Canaries Island, create a microclimate with a very homogeneous average temperature of about $16.7^{\circ} \mathrm{C}$ during the year (Bazairi et al., 2010). There is little difference between the average temperatures of the hottest and the coldest months. The coastal zone of Essaouira is endowed with ecological assets that have earned it a double protection status: Arganeraie Biosphere Reserve and site of biological and ecological interest (SIBE). The major economic activities in the Essaouira province include agriculture, fishing, mining, trade, industries, tourism, artisanal activities and handicraft industry.

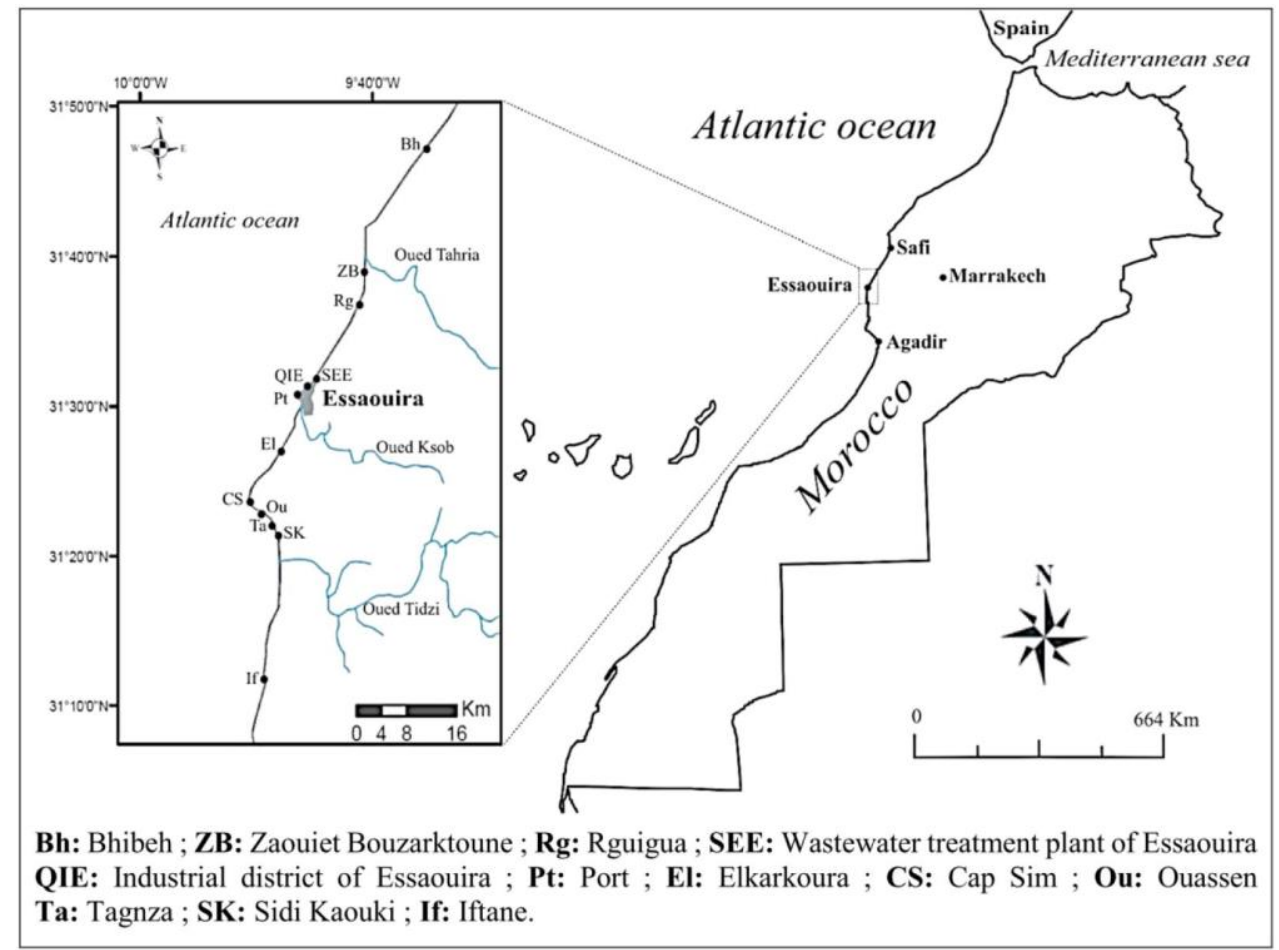

Figure 1. Geographical position of study area and sampling sites for benthic polychaetes along the coast of Essaouira $\left(9^{\circ} 20^{\prime}\right.$ and $9^{\circ} 90^{\prime} \mathrm{W} ; 31^{\circ} 10^{\prime}$ and $\left.31^{\circ} 50^{\prime} \mathrm{N}\right), \mathrm{NW}$ Morocco 


\section{Sampling and laboratory techniques}

Twelve sampling sites were investigated in summer 2016 (Fig. 1; Table 1). The samples were collected using a quadrat method (Misra, 1968) with four quadrats (each $25 \times 25 \mathrm{~cm}$, surface area $0.0625 \mathrm{~m}^{2}$ ) in the intertidal zone of each site. Sampling was done by scraping the surface layer (sediments, algae) and digging $2 \mathrm{~cm}$ deep in the hard substratum using a hammer. The material was manually collected and then fixed in formaldehyde (8\%). Water parameters such as $\mathrm{pH}$, conductivity and temperature were recorded in situ using a multi-parameter (type VMR MU $6100 \mathrm{H}$, Germany), and the salinity was calculated from the conductivity and temperature of sea water (Aminot and Kérouel, 2004). At the same time, the length (m) of each rocky shore was measured from the low water to high water using a measuring tape. Rocks of $20 \mathrm{~cm}$ in length and $15 \mathrm{~cm}$ in width were collected for each sampling site using a hammer. All these samples were at least triplicated at each site to ensure the representativeness of the samples and measured parameters. In the laboratory, biological samples were rinsed in freshwater and preserved in $70 \%$ ethanol and the polychaetes were identified to species when possible with assistance of Dr. Patrick Gillet (Catholic University of the West, France) using various guides, e.g., Fauvel $(1923,1927)$ and Fauchald (1977), and then counted and weighed. The rock samples were cut and dozens of thin sections were prepared (Fig. 2), then grains size from these thin sections were measured using polarizing optical microscope (OLYMPUS BH 2), and the void percentage in each thin section was estimated using "Chart for estimating mineral grain percentage composition of rocks and sediments" (Compton, 1962).

Table 1. Numbers, names, abbreviation codes and GPS coordinates of the sampling sites

\begin{tabular}{c|c|c|c|c}
\hline $\begin{array}{c}\text { Site } \\
\text { number }\end{array}$ & Site name & Abbreviation code & Latitude & Longitude \\
\hline 1 & Bhibeh & $\mathrm{Bh}$ & $31^{\circ} 47^{\prime} 55^{\prime \prime} \mathrm{N}$ & $9^{\circ} 34^{\prime} 59^{\prime \prime} \mathrm{W}$ \\
2 & Zaouiet Bouzarktoune & $\mathrm{ZB}$ & $31^{\circ} 38^{\prime} 51^{\prime \prime} \mathrm{N}$ & $9^{\circ} 40^{\prime} 41^{\prime \prime} \mathrm{W}$ \\
3 & Rguigua & $\mathrm{Rg}$ & $31^{\circ} 36^{\prime} 46^{\prime \prime} \mathrm{N}$ & $9^{\circ} 41^{\prime} 12^{\prime \prime} \mathrm{W}$ \\
4 & Wastewater treatment plant of Essaouira & $\mathrm{SEE}$ & $31^{\circ} 31^{\prime} 53^{\prime \prime} \mathrm{N}$ & $9^{\circ} 45^{\prime} 02^{\prime \prime} \mathrm{W}$ \\
5 & Industrial district of Essaouira & $\mathrm{QIE}$ & $31^{\circ} 31^{\prime} 21^{\prime \prime} \mathrm{N}$ & $9^{\circ} 45^{\prime} 38^{\prime \prime} \mathrm{W}$ \\
6 & Port & $\mathrm{Pt}$ & $31^{\circ} 30^{\prime} 43^{\prime \prime} \mathrm{N}$ & $9^{\circ} 46^{\prime} 27^{\prime \prime} \mathrm{W}$ \\
7 & Elkarkoura & $\mathrm{El}$ & $31^{\circ} 26^{\prime} 55^{\prime \prime} \mathrm{N}$ & $9^{\circ} 48^{\prime} 01^{\prime \prime} \mathrm{W}$ \\
8 & Cap Sim & $\mathrm{CS}$ & $31^{\circ} 24^{\prime} 02^{\prime \prime} \mathrm{N}$ & $9^{\circ} 50^{\prime} 37^{\prime \prime} \mathrm{W}$ \\
9 & Ouassen & $\mathrm{Ou}$ & $31^{\circ} 23^{\prime} 02^{\prime \prime} \mathrm{N}$ & $9^{\circ} 49^{\prime} 12^{\prime \prime} \mathrm{W}$ \\
10 & Tagnza & $\mathrm{Ta}$ & $31^{\circ} 22^{\prime} 18^{\prime \prime} \mathrm{N}$ & $9^{\circ} 48^{\prime} 31^{\prime \prime} \mathrm{W}$ \\
11 & Sidi Kaouki & $\mathrm{SK}$ & $31^{\circ} 21^{\prime} 24^{\prime \prime} \mathrm{N}$ & $9^{\circ} 48^{\prime} 08^{\prime \prime} \mathrm{W}$ \\
12 & Iftane & If & $31^{\circ} 11^{\prime} 54^{\prime \prime} \mathrm{N}$ & $9^{\circ} 49^{\prime} 20^{\prime \prime} \mathrm{W}$ \\
\hline
\end{tabular}

\section{Polychaetes feeding guild assignments}

In this study, we assigned feeding guilds to all polychaetes collected according to the definitions of Fauchald and Jumars (1979), MacDonald et al. (2010) and Jumars et al. (2015), which are based on the stomach content analysis of polychaetes and also direct observations of feeding behavior. Feeding guilds of polychaetes are divided into two modes (macrophagous and microphagous) and five or six sub-modes (herbivores, carnivores, filter feeders, surface deposit feeders, burrowers and omnivores), according 
to their major feeding modes. The motility pattern was classified into motile, discretely motile and sessile, and the morphological structures used in feeding were classified into jawed, pumping, tentaculate or other structures, which are usually eversible sac-like pharynges (Fauchald and Jumars, 1979; MacDonald et al., 2010; Jumars et al., 2015). The feeding guilds annotations was performed as follows (Table 2): in the three letter codes, the letter in the first position indicates major mode, the second the motility pattern, and the last letter indicates the morphological structure used in feeding; in position 1:B, subsurface deposit feeder (burrower); C, carnivore; F, filter feeder; $\mathrm{H}$, herbivore; O, Omnivore; S, surface deposit feeder; in position 2:D, discretely motile; M, motile; S, sessile; in position 3:J, jawed; T, tentaculate; $\mathrm{X}$, other structures, usually eversible sac-like pharynges.

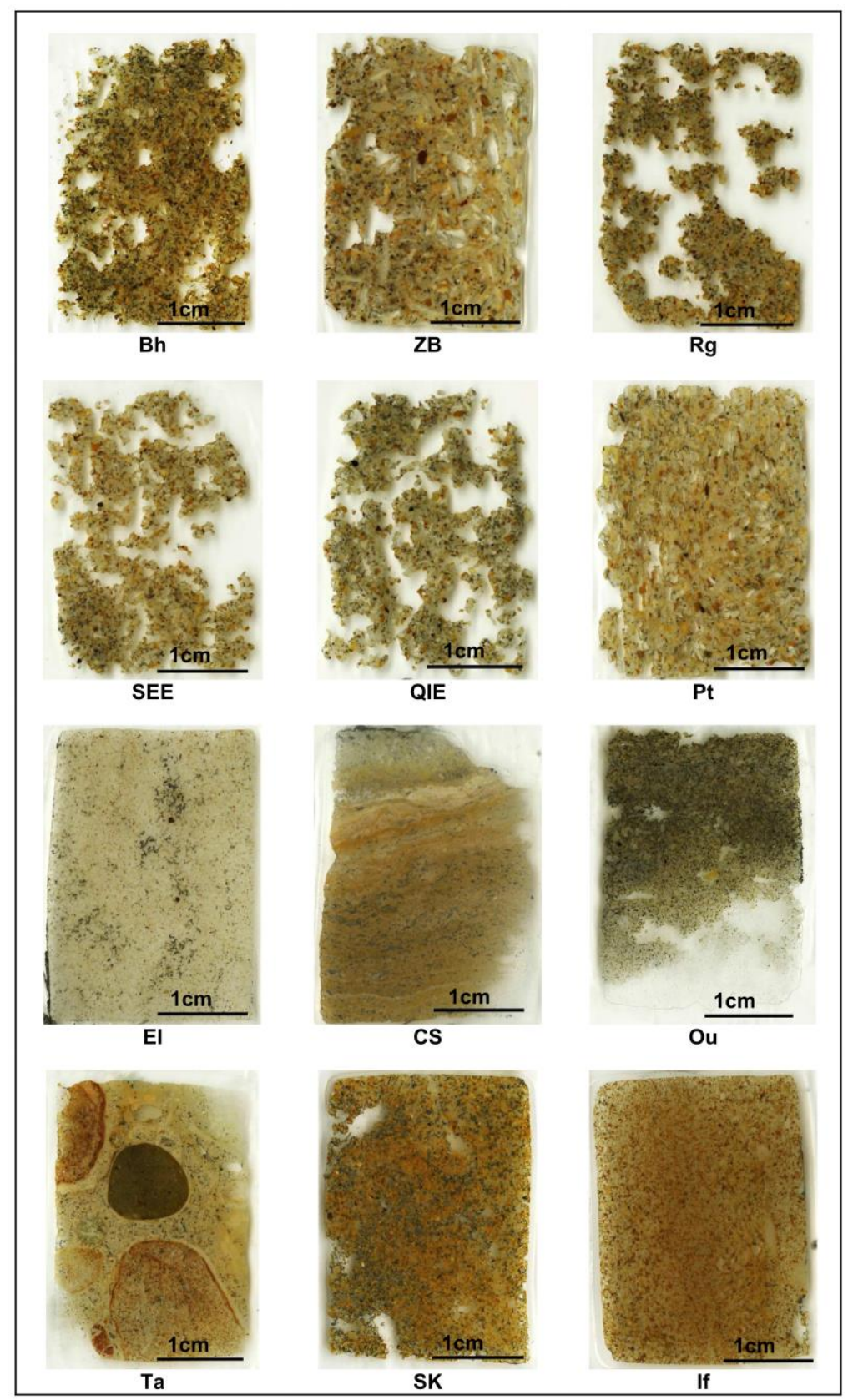

Figure 2. Photos of thin sections showing grain size of sampled rocks in the study area 
Table 2. Feeding guilds annotations of polychaetes after Fauchald and Jumars (1979), MacDonald et al. (2010) and Jumars et al. (2015)

\begin{tabular}{c|c|c|c}
\hline & Motile & Discretely motile & Sessile \\
\hline Macrophagous modes & & & \\
Herbivores & HMX & & \\
Unarmed pharynx & HMJ & HDJ & \\
Jawed pharynx & & & \\
Carnivores & CMX & & \\
Unarmed pharynx & CMJ & CDJ & \\
Jawed pharynx & & & FST \\
Microphagous modes & & FSP \\
Filter feeders & & FDT & \\
Tentaculate & FDP & \\
pumping & & & \\
Surface deposit feeders & SMX & SDX & SST \\
Unarmed pharynx & SMJ & SDJ & BSX \\
Jawed pharynx & SMT & SDT & \\
Tentaculate & BMX & BDX & \\
Burrowers & BMJ & & \\
Unarmed pharynx & BMT & & \\
Jawed pharynx & & & \\
Tentaculate & & & \\
\hline
\end{tabular}

\section{Statistical analysis}

The trophic importance of each group was evaluated according to the trophic importance index (TI) proposed by Paiva (1994) and modified by Muniz and Pires (1999), using the following equation (Eq. 1):

$$
\mathrm{TI}=\sum_{\mathrm{i}=1}^{\mathrm{s}} \ln n i(+0.1)
$$

where $s$ is the number of species of a trophic group in the sample, $\ln$ is the natural logarithm, $n_{i}$ is the number of individuals of the $i$ th species in the sample, and 0.1 is a constant.

The index of trophic diversity (1-ITD) was calculated as follows (Eq. 2):

$$
\operatorname{ITD}=\sum \theta^{2}
$$

where $\theta$ is the contribution of the density of each trophic group to the total polychaete density. The 1-ITD ranged from 0.90 (the highest trophic diversity) to 0.0 (the lowest diversity; i.e. one trophic guild accounts for $100 \%$ of the polychaete density: Heip et al., 1985). The taxonomic similarity between sampling sites was elucidated by a cluster analysis (Bray-Curtis similarity, Complete Link) based on the values of trophic 
importance index (TI). This analysis was carried out using the BioDiversity Pro statistical program (Version 2.0).

One-way ANOVA (analysis of variance) and Tukey's test were used to evaluate statistically significant differences of environmental variables means and Trophic Index means between the sampling sites. CCA (canonical correspondence analysis) was performed to explore the distribution of the polychaete feeding guilds in relation to the rocky shores and environmental factors. One-way ANOVA, Tukey's test and CCA analysis were conducted using the PAST software package (Hammer et al., 2001), Statistical Version 3.15 for Windows software.

\section{Results}

\section{Environmental variables}

The environmental characterization of the study area was presented in Table 3. The longest and shortest rocky beach measured were of $271.67 \pm 12.58 \mathrm{~m}(\mathrm{CS})$ and $88.33 \pm$ $7.64 \mathrm{~m}(\mathrm{Pt})$, respectively. The void percentage in the rock ranged from $1.00 \pm 0.04 \%$ (El) to $43.00 \pm 5.77 \%$ (QIE). The mean grain sizes varied from $0.19 \pm 0.10 \mathrm{~mm}$ to 6.83 $\pm 6.27 \mathrm{~mm}$ on the $(\mathrm{CS})$ and $(\mathrm{Ta})$ rocky shores, respectively. The seawater temperature showed fluctuations between the sampling sites with a minimum value recorded at $\mathrm{Pt}$ $\left(17.50 \pm 0.50{ }^{\circ} \mathrm{C}\right)$ and a maximum value at $\operatorname{SEE}\left(21.00 \pm 0.15^{\circ} \mathrm{C}\right)$. The $\mathrm{pH}$ value showed a similar trend, ranging from $8.00 \pm 0.01(\mathrm{Ou})$ to $8.51 \pm 0.01$ (If). The values of conductivity were typical of seawater, $\left(\sim 50 \mathrm{~ms} . \mathrm{cm}^{-1}\right.$, Rodier et al., 2009). The salinity was relatively high compared to the average oceanic salinity (35\%) and ranged from $36.26 \pm 0.24 \%$ o (SEE) to $39.81 \pm 0.08 \%$ (Pt). The differences in mean values of these environmental variables were found to be significant at all sites $(\mathrm{p}<0.05)$ except for conductivity.

Table 3. Environmental characterization of the study area, based on variables measured at the 12 rocky shores of Essaouira coastline (mean value \pm standard deviation, $N=3$ )

\begin{tabular}{|c|c|c|c|c|c|c|c|}
\hline Site & Length (m) & $\begin{array}{l}\text { Void percentage } \\
\text { in the rock }(\%)\end{array}$ & $\begin{array}{c}\text { Grain size } \\
(\mathrm{mm})\end{array}$ & $\begin{array}{c}\text { Water temp. } \\
\left({ }^{\circ} \mathrm{C}\right)\end{array}$ & pH & $\begin{array}{c}\text { Conductivity } \\
\left(\text { ms.cm }^{-1}\right)\end{array}$ & Salinity (\%) \\
\hline $\mathrm{Bh}$ & 160.3 & $20.00 \pm 3.92^{B}$ & $0.47 \pm 0.29^{\mathrm{B}}$ & $18.70 \pm 0.60^{\mathrm{C}}$ & $8.20 \pm 0$. & $50.90 \pm 0.90^{\mathrm{A}}$ & 38.6 \\
\hline $\mathrm{ZB}$ & $150.00 \pm 7.07^{\mathrm{DE}}$ & $9.00 \pm 1.41^{\mathrm{C}}$ & $0.67 \pm 0.53^{\mathrm{B}}$ & $20.90 \pm 0.14^{\mathrm{A}}$ & $8.28 \pm 0.01^{\mathrm{BC}}$ & $50.80 \pm 0.24^{\mathrm{A}}$ & $36.59 \pm 0.11^{\mathrm{FG}}$ \\
\hline $\mathrm{Rg}$ & $164.33 \pm 5.13^{\mathrm{CD}}$ & $42.00 \pm 10.61^{\mathrm{A}}$ & $0.28 \pm 0.17^{\mathrm{B}}$ & $19.10 \pm 0.08^{\mathrm{BC}}$ & $8.18 \pm 0.03^{\mathrm{CD}}$ & $50.90 \pm 0.13^{\mathrm{A}}$ & $38.28 \pm 0.05^{\mathrm{CD}}$ \\
\hline SEE & $109.33 \pm 9.02^{\mathrm{FG}}$ & $38.00 \pm 3.56^{\mathrm{A}}$ & $0.38 \pm 0.20^{\mathrm{B}}$ & $21.00 \pm 0.15^{\mathrm{A}}$ & $8.15 \pm 0.13^{\mathrm{CD}}$ & $50.50 \pm 0.44^{\mathrm{A}}$ & $36.26 \pm 0.24^{G}$ \\
\hline QIE & $131.67 \pm 10.41^{\mathrm{EF}}$ & $43.00 \pm 5.77^{\mathrm{A}}$ & $0.60 \pm 0.24^{\mathrm{B}}$ & $18.38 \pm 0.17^{\mathrm{CD}}$ & $8.08 \pm 0.13^{\mathrm{CD}}$ & $50.90 \pm 0.52^{\mathrm{A}}$ & $0.29^{\mathrm{BC}}$ \\
\hline $\mathrm{Pt}$ & $88.33 \pm 7.64^{\mathrm{G}}$ & $7.00 \pm 0.41^{\mathrm{C}}$ & $0.68 \pm 0.25^{\mathrm{B}}$ & $17.50 \pm 0.50^{\mathrm{D}}$ & $8.04 \pm 0.14^{\mathrm{D}}$ & $50.90 \pm 0.56^{\mathrm{A}}$ & $39.81 \pm 0.08^{\mathrm{A}}$ \\
\hline $\mathrm{El}$ & $188.33 \pm 10.41^{\mathrm{C}}$ & $00 \pm 0.04^{\mathrm{C}}$ & $0.23 \pm 0.07^{\mathrm{B}}$ & $20.00 \pm 0.87^{\mathrm{AB}}$ & $8.10 \pm 0.01^{\mathrm{CD}}$ & $50.60 \pm 0.26^{\mathrm{A}}$ & $37.22 \pm 0.65^{\mathrm{EF}}$ \\
\hline $\mathrm{CS}$ & $271.67 \pm 12.58^{\mathrm{A}}$ & $1.50 \pm 0.41^{\mathrm{C}}$ & $0.19 \pm 0.10^{\mathrm{B}}$ & $20.70 \pm 0.30^{\mathrm{A}}$ & $8.43 \pm 0.03^{\mathrm{AB}}$ & $50.80 \pm 0.13^{\mathrm{A}}$ & $36.76 \pm 0.21^{\mathrm{FG}}$ \\
\hline $\mathrm{Ou}$ & $163.33 \pm 5.77^{\mathrm{CD}}$ & $10.00 \pm 3.65^{\mathrm{C}}$ & $0.33 \pm 0.11^{\mathrm{B}}$ & $19.00 \pm 0.03^{\mathrm{BC}}$ & $8.00 \pm 0.01^{\mathrm{D}}$ & $50.00 \pm 0.01^{\mathrm{A}}$ & $37.61 \pm 0.03^{\mathrm{DE}}$ \\
\hline $\mathrm{Ta}$ & $230.00 \pm 15.00^{\mathrm{B}}$ & $1.00 \pm 0.12^{\mathrm{C}}$ & $6.83 \pm 6.27^{\mathrm{A}}$ & $18.00 \pm 0.50^{\mathrm{CD}}$ & $8.10 \pm 0.03^{\mathrm{CD}}$ & $51.00 \pm 0.08^{\mathrm{A}}$ & $39.41 \pm 0.42^{\mathrm{AB}}$ \\
\hline SK & $172.67 \pm 7.51^{\mathrm{CD}}$ & $7.00 \pm 1.15^{\mathrm{C}}$ & $0.67 \pm 0.16^{\mathrm{B}}$ & $18.20 \pm 0.27^{\mathrm{CD}}$ & $8.19 \pm 0.05^{\mathrm{CD}}$ & $51.00 \pm 0.62^{\mathrm{A}}$ & $39.22 \pm 0.37^{\mathrm{AB}}$ \\
\hline If & $170.00 \pm 10.00^{\mathrm{CD}}$ & $3.00 \pm 0.41^{\mathrm{C}}$ & $0.52 \pm 0.10^{\mathrm{B}}$ & $18.50 \pm 0.10^{\mathrm{CD}}$ & $8.51 \pm 0.01^{\mathrm{A}}$ & $50.90 \pm 0.09^{\mathrm{A}}$ & $38.84 \pm 0.05^{\mathrm{BC}}$ \\
\hline
\end{tabular}

*The different upper-case letters in the same row show the differences between sites $(\mathrm{p}<0.05)$

\section{Taxonomic and feeding guild composition}

In this study, 42 polychaete species belonging to 29 genera and 16 families were identified among the 4517 specimens collected (see Appendix). The mean biomass 
(expressed as $\mathrm{g}$ wet weight per $\mathrm{m}^{2}$, with $0.001 \mathrm{~g}$ accuracy) was found to be $37.61 \pm$ 15.80 g.m $\mathrm{m}^{-2}$. The abundance of polychaetes varied from 388 individuals per $\mathrm{m}^{2}$ (ind. $\mathrm{m}^{-2}$ ) at Elkarkoura site to 3388 ind. $\mathrm{m}^{-2}$ at Iftane site. The number of species ranged between 13 and 27 with the highest number ( 27 species) observed at Iftane site which is $51 \mathrm{~km}$ from any source of urban pollution of Essaouira city, and the lowest species number (13 species) at the site SEE. The latter site is within the effluent outflow of the wastewater treatment plant of Essaouira. Families such as Sabellaridae (24\% of the individuals), Nereididae (23\%), Orbiniidae (9\%), Lumbrinereidae (9\%) and Terebellidae (8\%) were found to be dominant in terms of abundance. Sabellaria alveolata ranked as the top species in abundance (24\%), followed by Perinereis cultrifera (12\%), Platynereis dumerilii (8\%), Terbella lapidaria (8\%), Scoletoma impatiens (8\%) and Scolaricia typica $(8 \%)$.

The polychaete assemblage found in the study area comprised five different feeding types, namely; surface deposit feeders, carnivores, filter feeders, subsurface deposit feeders, omnivores, and nine feeding modes: BDX (burrower, discretely motile, other structures), CMX (carnivore, motile, other structures), SDT (surface deposit feeder, discretely motile, with tentacles), CMJ (carnivore, motile, with jaw apparatus), BMJ (burrower, motile, with jaw apparatus), ODJ (omnivore, discretely motile, with jaw apparatus), BMX (burrower, motile, other structures), FDT (filter feeder, discretely motile, with tentacles) and FST (filter feeder, sessile, with tentacles) (Table 4).

Table 4. List of polychaete taxa recorded throughout the sampling sites and relevant feeding guilds. In the three letter codes, the letter in the first position indicates major mode, the second the motility pattern, and the last letter indicates the morphological structure used in feeding; in position 1:B, subsurface deposit feeder (burrower); C, carnivore; $F$, filter feeder; $H$, herbivore; $O$, Omnivore; $S$, surface deposit feeder; in position 2:D, discretely motile; $M$, motile; $S$, sessile; in position 3:J, jawed; T, tentaculate; $X$, other structures, usually eversible sac-like pharynges

\begin{tabular}{|c|c|c|c|c|c|}
\hline Species & $\begin{array}{c}\text { Feeding } \\
\text { guilds }\end{array}$ & Feeding modes & Species & $\begin{array}{c}\text { Feeding } \\
\text { guilds }\end{array}$ & $\begin{array}{c}\text { Feeding } \\
\text { modes }\end{array}$ \\
\hline Capitellidae sp & B & BDX & Orbiniidae sp & B & BMX \\
\hline Bhawania goodei & $\mathrm{C}$ & CMX & Eulalia viridis & $\mathrm{C}$ & CMX \\
\hline Cirratulidae sp & $S$ & SDT & Mysta picta & $\mathrm{C}$ & CMX \\
\hline Cirriformia tentaculata & S & SDT & Pyhllodoce maculta & $\mathrm{C}$ & CMX \\
\hline Lysidice ninetta & $\mathrm{C}$ & $\mathrm{CMJ}$ & Lepidonotus clava & $\mathrm{C}$ & $\mathrm{CMJ}$ \\
\hline Marphysa sp & $\mathrm{C}$ & $\mathrm{CMJ}$ & Polynoidae sp & $\mathrm{C}$ & $\mathrm{CMJ}$ \\
\hline Nematonereis unicornis & $\mathrm{C}$ & $\mathrm{CMJ}$ & Sabellaria alveolata & $\mathrm{F}$ & FDT \\
\hline Scoletoma funchalensis & B & $\mathrm{BMJ}$ & Dasychone lucullana & $\mathrm{F}$ & FST \\
\hline Scoletoma impatiens & $\mathrm{B}$ & $\mathrm{BMJ}$ & Jasmineira elegans & $\mathrm{F}$ & FST \\
\hline Lumbrinereis $s p$ & $\mathrm{~B}$ & $\mathrm{BMJ}$ & Spirobranchus triqueter & $\mathrm{F}$ & FST \\
\hline Johnstonia clymenoides & B & $\mathrm{BDX}$ & Spirorbis $s p$ & $\mathrm{~F}$ & FST \\
\hline Petaloproctus terricola & $\mathrm{B}$ & BDX & Serpula vermicularis & $\mathrm{F}$ & FST \\
\hline Maldanidae sp & $\mathrm{B}$ & BDX & Serpulidae sp & $\mathrm{F}$ & FST \\
\hline Perinereis cultrifera & $\mathrm{O}$ & ODJ & Nerinides cantabra & $S$ & SDT \\
\hline Perinereis marionii & $\mathrm{O}$ & ODJ & Polydora ciliata & $\mathrm{S}$ & SDT \\
\hline Platynereis dumerilii & $\mathrm{O}$ & ODJ & Aonides oxycephala & $\mathrm{S}$ & SDT \\
\hline Nereis irrorata & $\mathrm{O}$ & ODJ & Syllis armillaris & $\mathrm{C}$ & CMJ \\
\hline Nereis sp & $\mathrm{O}$ & ODJ & Syllidae sp 1 & $\mathrm{C}$ & $\mathrm{CMJ}$ \\
\hline Nereididae sp & $\mathrm{O}$ & ODJ & Syllidae sp 2 & $\mathrm{C}$ & $\mathrm{CMJ}$ \\
\hline Scolaricia typica & $\mathrm{B}$ & $\mathrm{BMX}$ & Terebella lapidaria & $\mathrm{S}$ & SDT \\
\hline Nainereis laevigata & B & BMX & Terebellidae sp & $\mathrm{S}$ & SDT \\
\hline
\end{tabular}


On the intertidal rocky shores of Essaouira, the filter feeders were the dominant feeding guild (32\%) followed by omnivores (23\%), burrowers $(20 \%)$, carnivores $(15 \%)$ and surface deposit-feeders (10\%) (Fig. 3A). The FDT was the most abundant feeding mode, accounting for $24 \%$ of abundance (mainly represented by Sabellaria alveolata), followed by the ODJ feeding mode with $22 \%$, and the SDT feeding mode with $18.9 \%$ (Fig. 3B), it seems that these 3 groups were present in almost similar proportions. Most feeding modes occurred at all studied sites (12 sampling sites), except for SDT feeding mode absent from the EL site, and the BMX feeding mode absent from the SEE and EL sampling sites.

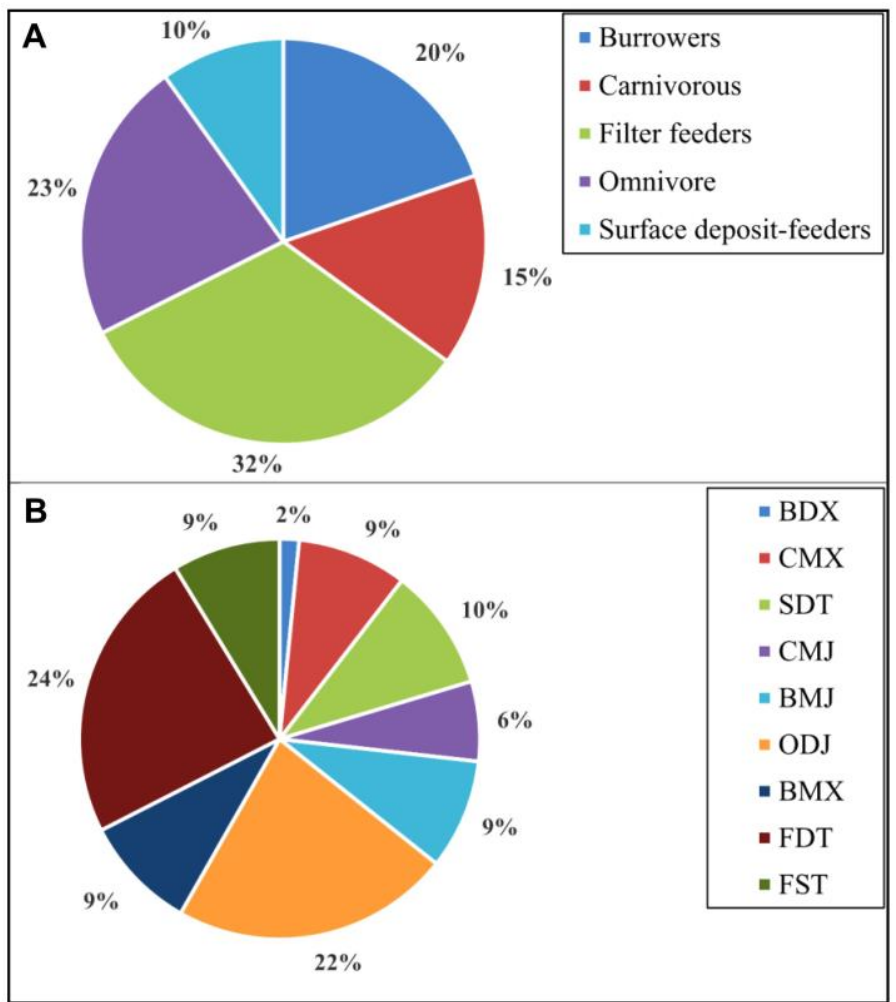

Figure 3. Relative abundance (\%) of the feeding guilds (A) and feeding Modes (B) of polychaetes sampled in the study area. BDX (burrower, discretely motile, other structures); CMX (carnivore, motile, other structures); SDT (surface deposit feeder, discretely motile, with tentacles); CMJ (carnivore, motile, with jaw apparatus); BMJ (burrower, motile, with jaw apparatus); ODJ (omnivore, discretely motile, with jaw apparatus); BMX (burrower, motile, other structures); FDT (filter feeder, discretely motile, with tentacles); FST (filter feeder, sessile, with tentacles)

\section{Feeding guild characterization}

The spatial distribution of feeding guilds at different sampling sites of Essaouira intertidal rocky shores is presented in Figure 4. The results of a one way ANOVA shows a highly significant difference $(\mathrm{F}=2.46 ; \mathrm{df}=11 ; \mathrm{N}=5 ; \mathrm{Pp}<0.05)$ of Trophic Index mean between the investigated sites. The burrowers were very common in the studied area, and the most abundant species were Scoletoma impatiens and Scolaricia typica. The highest TI of this feeding guild was recorded at CS, SK and QIE sampling sites, with $\mathrm{TI}=33.97, \mathrm{TI}=32.91$ and $\mathrm{TI}=32.62$ respectively. The lowest $\mathrm{TI}$ was 
recorded at $\mathrm{ZB}(\mathrm{TI}=12.23)$ and $\mathrm{EL}$ sites $(\mathrm{TI}=15.58)$. Carnivores were very abundant in the study area, and the main species of this group were Bhawania goodei and Eulalia viridis. Their Trophic index was highest at If $(\mathrm{TI}=42.45)$ and lowest at CS $(\mathrm{TI}=12.80)$. Filter feeders were abundant in the whole study area, and represented mainly by Sabellaria alveolata. The highest TI of this group was recorded in the southern region of Essaouira, with $\mathrm{TI}=34.54, \mathrm{TI}=32.91$ and $\mathrm{TI}=31.86$ at $\mathrm{Ta}, \mathrm{SK}$ and If, respectively. The lowest TI was recorded north of Essaouira at SEE (TI = 8.86) and $\mathrm{ZB}$ sites $(\mathrm{TI}=12.80)$. Omnivores were also common in the study area, but not very abundant as compared to filter feeders. Their main representative species were Perinereis cultrifera and Platynereis dumerilii. The highest TI of this group was recorded in Essaouira city with $\mathrm{TI}=22.40$ at Pt. The lowest TI was recorded south of Essaouira at $\mathrm{Ou}(\mathrm{TI}=7.92)$. Finally, the surface deposit-feeders, represented mainly by Terebella lapidaria, were not very common in the study area because of their absence in the El sampling site. The highest TI of surface deposit-feeders was recorded at the southernmost site at If $(\mathrm{TI}=26.57)$, and the lowest $\mathrm{TI}$ was recorded north of Essaouira at $\mathrm{ZB}(\mathrm{TI}=4.14)$.

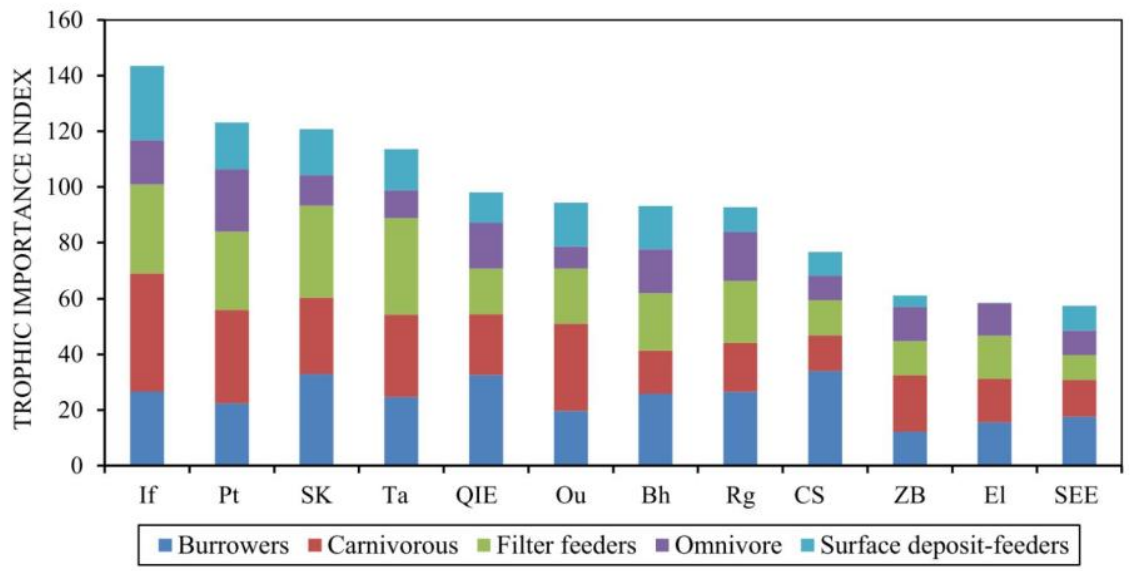

Figure 4. Trophic importance index values for sampling sites of Essaouira rocky shores

The index of trophic diversity (1-ITD) values were highest south of Essaouira (Ou, If, Ta, CS, El and SK sampling sites) and lowest in the urban area of Essaouira at QIE (Fig. 5).

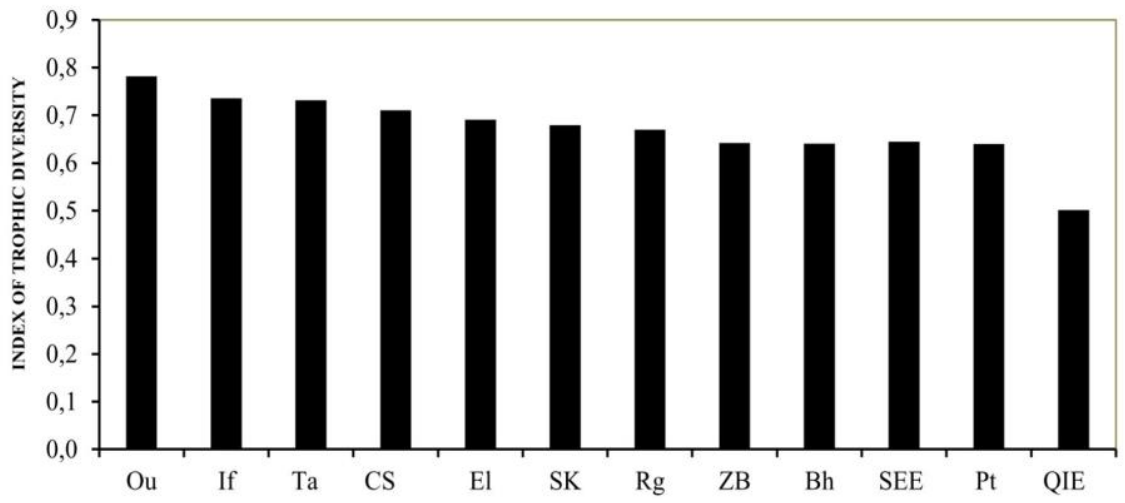

Figure 5. Index of trophic diversity values for the sampling sites of Essaouira rocky shores 
The results of the cluster analysis based on the values of trophic importance index (TI) are illustrated in Figure 6.

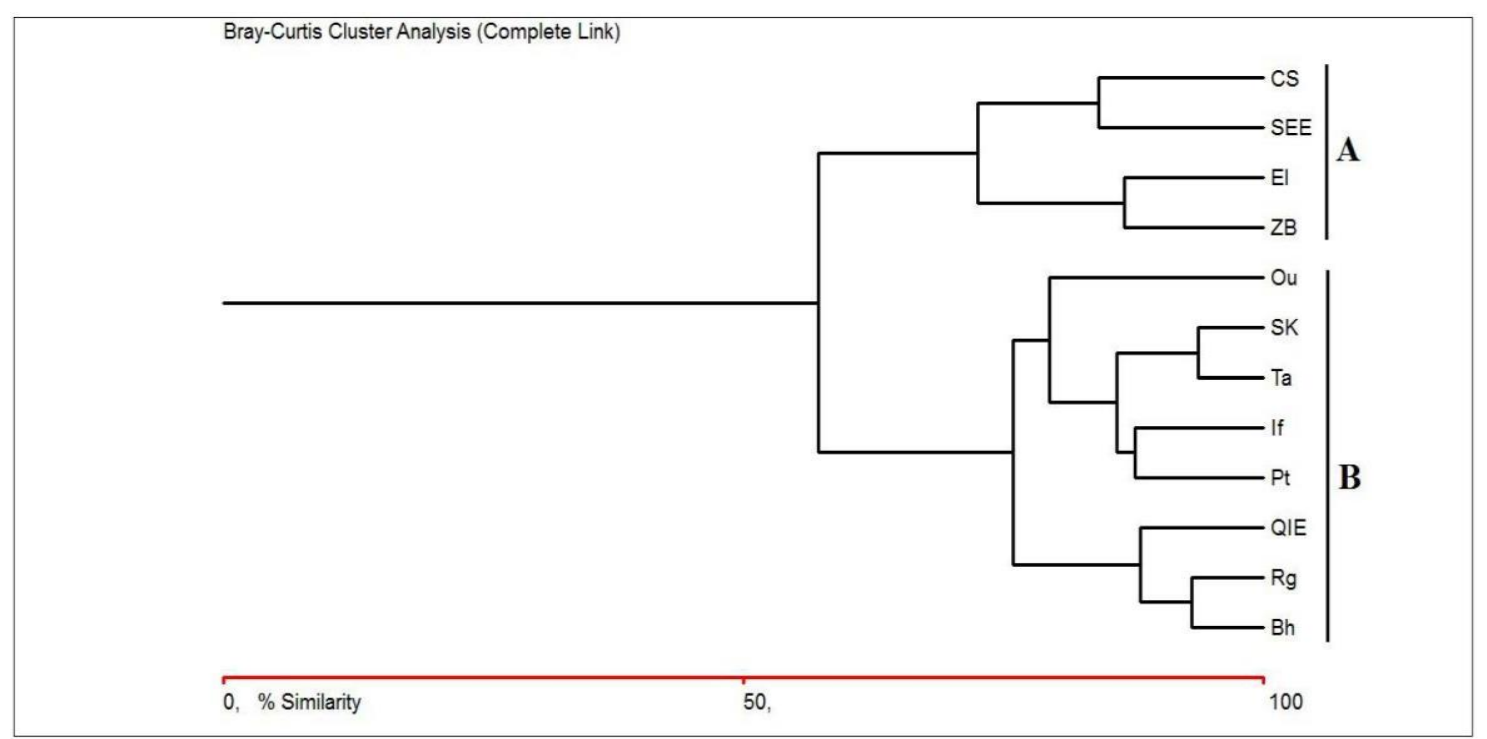

Figure 6. Distinct groups of sites established by cluster analysis for the 12 sampling sites considered on Essaouira coastline

According to these analyses, there are two distinct assemblages (A and B) with a level of dissimilarity less than 50\% even though both groups included five feeding guilds and nine feeding modes:

- Group A consists of four rocky sites (ZB, El, SEE, and CS) and the dominant feeding guilds, burrower and filter feeder groups, comprised $26.89 \%$ and $26.77 \%$ of all individuals respectively, while ODJ was the most abundant feeding mode (23.84\%). This assemblage was characterized by a medium Trophic Importance index $(\mathrm{TI}=63.47 \pm 8.96)$ and moderately high Index of trophic diversity $(1-\mathrm{ITD}=0.67 \pm 0.034)($ Table 4$)$.

- Group B includes eight rocky sites (Ou, SK, Ta, If, Pt, QIE, Rg and Bh). The dominant feeding guild was filter feeder with $35.84 \%$ of all, while FDT was the most abundant feeding mode $(26.48 \%)$. This assemblage was characterized by a high Trophic Importance index $(\mathrm{TI}=109.93 \pm 18.47)$ and moderately high Index of trophic diversity $(1-\mathrm{ITD}=0.67 \pm 0.085)($ Table 5$)$.

Table 5. Feeding guild assemblage characteristics in the Essaouira coastline

\begin{tabular}{c|c|c}
\hline Parameters & Group A & Group B \\
\hline Site number & 4 & 8 \\
Total feeding guilds & 5 & 5 \\
Total feeding modes & 9 & 9 \\
Mean (TI) & $63.47 \pm 8.96$ & $109.93 \pm 18.47$ \\
Mean (1-ITD) & $0.67 \pm 0.034$ & $0.67 \pm 0.085$ \\
Dominant feeding guild & Burrower and Filter feeder & Filter feeder \\
Dominant feeding mode & ODJ & FDT \\
\hline
\end{tabular}




\section{Relationships between feeding guild composition of polychaetes and abiotic factors}

The canonical correspondence analysis (CCA) indicated that abiotic factors contributed significantly to explaining the variation in polychaete feeding guilds among the rocky shores studied. The first and second axes accounted for 39.7 and $29.9 \%$ of the variance observed in the feeding guild data, respectively. On the CCA plot (Fig. 7), communities at $\mathrm{Bh}, \mathrm{ZB}, \mathrm{Pt}, \mathrm{El}, \mathrm{SK}$ and If are moderately associated with salinity. By contrast, communities at $\mathrm{Ta}$ and $\mathrm{Ou}$ (but not $\mathrm{Rg}$ ) positively related to the length of the rocky shores, higher grain-size and higher water temperature but negatively with salinity.

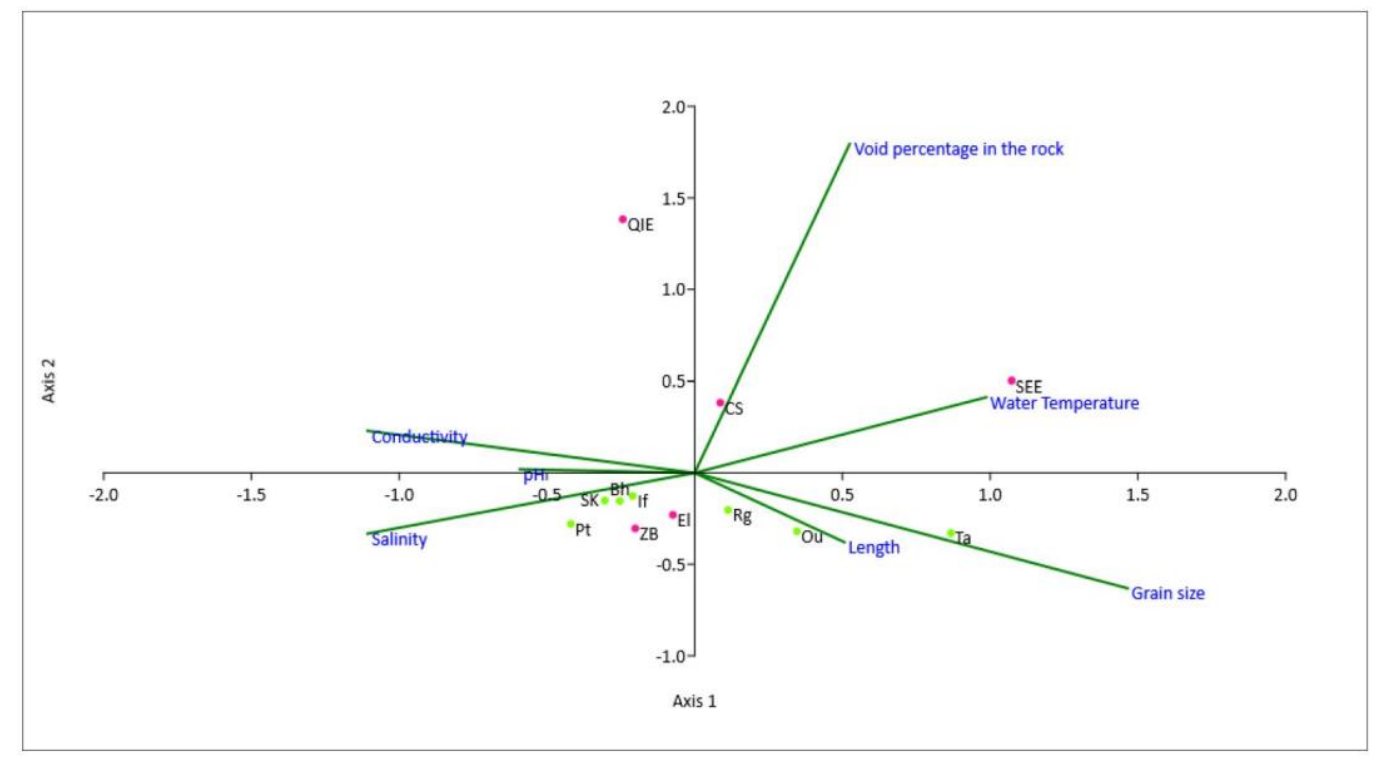

Figure 7. Canonical correspondence analysis (CCA) ordination of the polychaete feeding guild scores and environmental parameters in the study area (Axis 1: 39.7\%; Axis 2: 29.9\%)

\section{Discussion}

The present study provides the first characterization of the composition and spatial distribution patterns of polychaete feeding guilds along the rocky shores of Essaouira on the Atlantic coast of Morocco, and their relationship with environmental variables such as temperature, $\mathrm{pH}$, conductivity, salinity, length and void percentage in the rock, and grain size of the rock. In this study, polychaete feeding communities at 12 sites were classified into five feeding guilds (Surface deposit feeders, Carnivores, Filter feeders, Subsurface deposit feeders and Omnivores), and nine feeding modes (BDX, CMX, SDT, CMJ, BMJ, ODJ, BMX, FDT and FST). We have included the omnivore feeding guild in this work since it is difficult to assign some Nereids in a particular feeding guild. Fauchald and Jumars (1979) classified several Nereid species as both carnivores and herbivores. Later, Gaston (1987) characterized them as surface deposit-feeders, Bianchi and Morri (1985) featured them once again as herbivores, and Jumars et al. (2015) specified that Nereids are clearly omnivorous, although digestive physiology suggests more likely specialization. According to Lindsay and Woodin (1995), Hentschel and Larson (2005), there are some species that can change their feeding mode depending on the availability of resources. As there are no consensus in the literature, we preferred classifying the Nereids of Essaouira intertidal rocky shores as omnivores. 
The filter feeders were the dominant feeding guild (32\%) followed by omnivores $(23 \%)$, burrowers $(20 \%)$, carnivores $(15 \%)$ and surface deposit-feeders $(10 \%)$, and the FDT (filter feeder, discretely motile, with tentacles) was the most abundant feeding mode, followed by the ODJ feeding mode (omnivores, discretely motile, with jaw apparatus) and the SDT feeding mode (surface deposit feeder, discretely motile, with tentacles) accounting for $24 \%, 22 \%$ and $18.9 \%$ of abundance, respectively. Denny (1988) suggested that the wave action is one of the main factors influencing the establishment and development of intertidal and shallow subtidal benthic communities. This factor represents a constant stress source that forces populations to acquire specific adaptations that allow them to survive in a stressful environment. One of these adaptative aspects is the suspension-feeding mode, which allows organisms to feed on material brought in by water movements (Okamura, 1990; Mann and Lazier, 1991). Thus, it is not surprising that in our case this feeding guild was dominant and present in all study areas, and is probably further enhanced by the influx of nutrient-rich cold waters brought to the surface by upwelling. This phenomenon usually occurs from June to October (Belvèze, 1983; Gentile, 1997; Simone, 2000; Bazairi et al., 2010; Benazzouz, 2014). The main representative species of this guild was Sabellaria alveolata, contributing $73.2 \%$ to total filter feeder abundance. Similarly, other studies have shown a large number of polychaete feeding guilds in marine environments (Table 6). According to these studies, the filter-feeders were the dominant feeding guild on hard substrate while the depositfeeders were the dominant trophic group on soft substrates.

Table 6. Polychaete feeding guilds from different marine ecosystems and climate areas

\begin{tabular}{|c|c|c|c|c|c|c|}
\hline $\begin{array}{c}\text { Number of } \\
\text { trophic group } \\
\text { (number of } \\
\text { guilds) }\end{array}$ & $\begin{array}{c}\text { Number of } \\
\text { species } \\
\text { (number of } \\
\text { family) }\end{array}$ & $\begin{array}{c}\text { Dominant trophic } \\
\text { guild }\end{array}$ & Substrate & Ecosystem & Geographical area & Reference \\
\hline $5(9)$ & $42(16)$ & Filter-feeders & Hard & Intertidal & $\begin{array}{c}\text { Essaouira (Atlantic coast of } \\
\text { Morocco) }\end{array}$ & Present study \\
\hline $4(9)$ & $48(16)$ & Filter-feeders & Hard & Mussel bank & Thessaloniki Bay (Greece) & $\begin{array}{c}\text { Damianidis and } \\
\text { Chintiroglou } \\
(2000)\end{array}$ \\
\hline $4(4)$ & $22(3)$ & Filter-feeder & Hard & Reef & Valencia Gulf Coast (Spain) & $\begin{array}{l}\text { Porras et al. } \\
\text { (1996) }\end{array}$ \\
\hline $5(16)$ & $160(44)$ & Filter-feeders & $\begin{array}{l}\text { Muddy to } \\
\text { coarse sand }\end{array}$ & Subtidal & $\begin{array}{l}\text { Campeche Bank (southern } \\
\text { Gulf of Mexico) }\end{array}$ & $\begin{array}{c}\text { Castanedo et al. } \\
\text { (2012) }\end{array}$ \\
\hline 5 (n.a.) & $75(29)$ & $\begin{array}{l}\text { Surface deposit- } \\
\text { feeders }\end{array}$ & $\begin{array}{l}\text { Medium sand } \\
\text { to fine silt }\end{array}$ & $\begin{array}{c}\text { Continental } \\
\text { shelf }\end{array}$ & Southeast coast of India & $\begin{array}{c}\text { Manokaran et al. } \\
\text { (2013) }\end{array}$ \\
\hline $5(10)$ & $24(21)$ & Deposit-feeders & $\begin{array}{l}\text { Fine to coarse } \\
\text { sand }\end{array}$ & Sandy beach & $\begin{array}{c}\text { Sepetiba Bay (south-eastern } \\
\text { Brazil) }\end{array}$ & $\begin{array}{l}\text { Mattos et al. } \\
\text { (2012) }\end{array}$ \\
\hline 3 (n.a.) & $28(13)$ & $\begin{array}{l}\text { Surface deposit- } \\
\text { feeders }\end{array}$ & Soft bottom & Deep-sea & $\begin{array}{c}\text { Malta Escarpment (Western } \\
\text { Ionian Sea) }\end{array}$ & $\begin{array}{l}\text { Langeneck et al. } \\
\text { (2017) }\end{array}$ \\
\hline 5 (n.a.) & $92(25)$ & Deposit-feeders & Sand and mud & Intertidal & Gulf of Gabès (Tunisia) & $\begin{array}{l}\text { Mosbahi et al. } \\
\text { (2017) }\end{array}$ \\
\hline $4(13)$ & $83(12)$ & $\begin{array}{l}\text { Deposit-feeders } \\
\text { and carnivores }\end{array}$ & & Subtidal & Hong Kong (China) & $\begin{array}{l}\text { Cheung et al. } \\
\text { (2008) }\end{array}$ \\
\hline 3 (n.a.) & $15(10)$ & Deposit-feeders & $\begin{array}{l}\text { Fine to coarse } \\
\text { sand }\end{array}$ & Mangrove & $\begin{array}{l}\text { Quebra Pote, Maranhão } \\
\text { (Brazil) }\end{array}$ & $\begin{array}{l}\text { Cutrim et al. } \\
\qquad(2018)\end{array}$ \\
\hline $5(12)$ & $80(37)$ & Burrowers & $\begin{array}{l}\text { Fine sand to } \\
\text { coarse silt }\end{array}$ & Coastal bay & $\begin{array}{l}\text { Sishili Bay, the northern } \\
\text { Yellow Sea (China) }\end{array}$ & $\begin{array}{l}\text { Han et al. } \\
\text { (2016) }\end{array}$ \\
\hline
\end{tabular}


Paiva (1994) indicated that the density approach is more coherent to evaluate the importance of each feeding guild, especially when working with polychaete worms, since it indirectly estimates the biomass and production as these communities are composed of species with analogous life cycles. However, recruitment events and patchy distribution, not necessarily linked to increased food supply, can lead to an overevaluation of the feeding guild. Consequently, the use of the species richness gives more reliable results. During this study, we applied "Trophic group Importance index" (TI) proposed by Paiva (1994) which reduces the importance of density by applying log- transformation of abundances thus preserving the species richness factor. TI index was proved to be practical and very informative. Highest values of TI were recorded on the southern region of Essaouira where the beaches are sheltered and relatively far from human activities.

To accurately define the spatial organization of polychaete feeding guilds of Essaouira's rocky shores, we used the cluster method which allows a discrimination between the sampling sites. Spatial differences in the structure of polychaete feeding guilds clearly discriminated between two groups: the first was group A (sites ZB, El, SEE, and CS) that characterized by the dominance of burrower and filter feeder feeding guilds, and ODJ feeding mode. The second one was group B which includes eight rocky sites ( $\mathrm{Ou}, \mathrm{SK}$, Ta, If, Pt, QIE, Rg and $\mathrm{Bh}$ ), with the dominance of filter feeder feeding guild and FDT feeding mode.

Several authors have observed strong relationships between polychaete feeding guilds and environmental factors, among which granulometry of sediments seems to be the most important (Maurer and Leathem, 1981; Carrasco and Carbajal, 1998; Muniz and Pires, 1999; Pagliosa, 2005; Mattos et al., 2012). Muniz and Pires (1999) and Méndez (2013) concluded that organic matter level in sediments could also strongly influence the feeding guilds of polychaetes, while Carrasco and Carbajal (1998) found no relationship with this variable, but a strong influence of depth. According to Paiva (1994), depth contributes to the sediment stabilization and consequently increases the feeding guild variety. Salinity, dissolved oxygen and temperature were also found to be important factors in determining trophic structure (Maurer and Leathem, 1981; Castanedo et al., 2012). In this study, the CCA results indicate that the length of rocky shores and water temperature are the most influential factors on the composition and spatial distribution of polychaete feeding guilds. Indeed, the rocky shores of Essaouira are long and rich in microhabitats, providing habitats for a large range of species which favours the increase of feeding guild diversity in this area. However, water temperature acts negatively on the diversity and abundance of feeding guilds via its negative influence on species richness and abundance of polychaetes.

\section{Conclusion}

This study on the composition and spatial distribution of polychaete feeding guilds of Essaouira intertidal rocky shores led to the identification of five feeding guilds (Surface deposit feeders, Carnivores, Filter feeders, Subsurface deposit feeders and Omnivores), and nine feeding modes (BDX, CMX, SDT, CMJ, BMJ, ODJ, BMX, FDT and FST). Compared to other marine ecosystems and geographical areas, we can conclude that the rocky shore of Essaouira is relatively rich in polychaete feeding guilds. The abiotic factors such as length of rocky shores and water temperature are the major factors affecting the composition and spatial distribution of polychaete feeding guilds in this 
area. The data from this study can be used as a baseline reference for future scientific research programs, and may be a useful tool for authorities in charge of protection and management of this protected coastal area. Nevertheless, a detailed study during different seasons is required, in order to better understand the biotic and abiotic factors determining the structure and organisation of feeding guilds, determine the possible anthropogenic influences on this ecosystem, as well as to predict if this protected coastal area can be invaded by some invasive species.

\section{REFERENCES}

[1] Aminot, A., Kérouel, R. (2004): Hydrologie des écosystèmes marins. Paramètres et analyses. - Publisher Ifremer, Issy-les-Moulineaux, France, pp. 74-78.

[2] Arruda, E. P., Domaneschi, O., Amaral, A. C. Z. (2003): Mollusc feeding guilds on sandy beaches in São Paulo State, Brazil. - Marine Biology 143(4): 691-701.

[3] Bayed, A. (1991): Etude écologique des écosystèmes de plages de sable fin de la côte atlantique marocaine. Modèle de zonation, biotypologie, dynamique de population. $-\mathrm{PhD}$ Thesis Doctoral, Mohammed V University, Rabat, Morocco.

[4] Bazaïri, H., Bayed, A., Glémarec, M., Hily, C. (2003): Spatial organisation of macrozoobenthic communities in response to environmental factors in a coastal lagoon of the NW African coast (Merja Zerga, Morocco). - Oceanologica Acta 26(5-6): 457-471.

[5] Bazairi, H., Harmelin, J. G., Turpin, Y., Aghori, A. (2010): Caractérisation des peuplements marins de l'archipel de Mogador (Atlantique, MAROC). - Rapport du programme de coopération entre l'Initiative des Petites Îles de Méditerranée du Conservatoire de l'espace et littoral des rivages lacustres (République Française) et le Haut-Commissariat aux Eaux et Forêts et à la Lutte Contre la Désertification.

[6] Belan, T. A. (2004): Marine environmental quality assessment using polychaete taxocene characteristics in Vancouver Harbour. - Marine Environmental Research 57(1-2): 89101.

[7] Belvèze, H. (1983): Influence des facteurs hydroclimatiques sur la disponibilité en sardine (Sardina pilchardus Walbaum) dans la pêcherie marocaine atlantique. - Scientific Institute of Maritime Fisheries, Morocco.

[8] Benazzouz, A. (2014): Upwelling côtier et effet de la dynamique océanique à mésoéchelle sur la variabilité et la distribution planctonique dans le système d'upwelling du courant des canaries. - PhD Thesis Doctoral, Hassan II University, CasablancaMohammadia, Morocco.

[9] Bianchi, C. N., Morri, C. (1985): I policheti come descrittori della struttura trofica degli marini. - Oebalia 11(N. S.): 203-214.

[10] Carrasco, F., Carbajal, W. (1998): The distribution of polychaete feeding guilds in organic enriched sediments of San Vicente Bay, Central Chile. - International Review of Hydrobiology 83(3): 233-249.

[11] Castanedo, N. D., Alcántara, P. H., Solís-Weiss, V., Barba, A. G. (2012): Distribution of polychaete feeding guilds in sedimentary environments of the Campeche Bank, southern Gulf of Mexico. - Helgoland Marine Research 66(4): 469-478.

[12] Chaouti, A., Bayed, A. (2011): Structure and trophic organisation of the macrobenthic community of the Mediterranean lagoon of Smir (Morocco). - Bulletin de l'Institut Scientifique, Rabat, Section Sciences de la Vie 33(1): 1-12.

[13] Charrier, H. (1921): Note sur les Annélides Polychètes de la région de Tanger. - Bulletin de la Société des Sciences Naturelles et Physiques du Maroc I: 55-57.

[14] Cherkaoui, E., Bayed, A., Hily, C. (2003): Spatial organization of the macrobenthos in the Bou Regreg estuary, Moroccan Atlantic coast. - Cahiers de Biologie Marine 44(4): 339-352. 
[15] Cheung, S. G., Lam, N. W. Y., Wu, R. S. S., Shin, P. K. S. (2008): Spatio-temporal changes of marine macrobenthic community in sub-tropical waters upon recovery from eutrophication. II. Life-history traits and feeding guilds of polychaete community. Marine Pollution Bulletin 56(2): 297-307.

[16] Compton, R. R. (1962): Manual of Field Geology. - John Wiley \& Sons Ltd., New York.

[17] Cutrim, A. S. T., Sousa, L. K. S., Ribeiro, R. P., Oliveira, V. M., Almeida, Z. S. (2018): Structure of a polychaete community in a mangrove in the northern coast of Brazil. Acta Biológica Colombiana 23(3), 286-294.

[18] Damianidis, P., Chintiroglou, C. C. (2000): Structure and functions of polychaeteofauna living in Mytilus galloproincialis assemblages in Thermaikos Gulf (north Aegean Sea). Oceanologica Acta 23(3): 323-337.

[19] Dauwe, B., Herman, P. M. J., Heip, C. H. R. (1998): Community structure and bioturbation potential of macrofauna at four North Sea stations with contrasting food supply. - Marine Ecology Progress Series 173: 67-83.

[20] Denisenko, S. G., Denisenko, N. V., Lehtonen, K. K., Andersin, A. B., Laine, A. O. (2003): Macrozoobenthos of the Pechora Sea (SE Barents Sea): community structure and spatial distribution in relation to environmental conditions. - Marine Ecology Progress Series 258: 109-123.

[21] Denny, M. W. (1988): Biology and the Mechanics of the Wave-Swept Environment. Princeton University Press, New Jersey, USA.

[22] Fauchald, K. (1977): The polychaete worms. Definitions and keys to the order, families and genera. - Natural History Museum of Los Angeles County, Science Series 28: 1-190.

[23] Fauchald, K., Jumars, P. A. (1979): The diet of worms: a study of polychaete feeding guilds. - Oceanographic Marine Biology: Annual Review 17: 193-284.

[24] Fauvel, P. (1923): Faune de France. 5 Polychètes errantes. Addenda aux errantes, Archiannélides, Myzostomaires. Faune de France. - Lechevalier, Paris, 5: 1-488.

[25] Fauvel, P. (1927): Faune de France. 16 Polychètes sédentaires. Addenda aux errantes, Archiannélides, Myzostomaires. Faune de France. - Lechevalier, Paris, 16: 1-494.

[26] Gaston, G. R. (1987): Benthic polychaeta of the Middle Atlantic Bight: feeding and distribution. - Marine Ecology Progress Series 36: 251-262.

[27] Gentile, W. (1997): Caractérisation et suivi d'un champ dunaire par analyses sédimentologiques et télédétection: Essaouira - Cap Sim (Maroc atlantique). PhD Thesis Doctoral, University of Provence Aix-Marseille I, France.

[28] Giangrande, A., Licciano, M., Musco, L. (2005): Polychaetes as environmental indicators revisited. - Marine Pollution Bulletin 50(11): 1153-1162.

[29] Goumri, M., Gillet, P., Chaouti, A., Chouikh, N., Maarouf, A., Cheggour, M., Mouabad, A. (2017): First record of Boccardia polybranchia (Haswell, 1885) (Polychaeta: Spionidae) from the Atlantic coast of Morocco. - Journal of Materials and Environmental Science 8(10): 3606-3611.

[30] Grassle, J. F., Maciolek, N. J. (1992): Deep-sea species richness; regional and local diversity estimates from quantitative bottom sampling. - American Naturalist 139(2): 313-341.

[31] Hammer, Ø., Harper, D. A. T., Ryan, P. D. (2001): PAST: paleontological statistics software package for education and data analysis. - Palaeontol Electron 4: 1-9.

[32] Han, Q., Jiang, X., Wang, X. (2016): The polychaete feeding guild composition in the Sishili Bay, the northern Yellow Sea, China. - Journal of the Marine Biological Association of the United Kingdom 96(5): 1083-1092.

[33] Heip, C., Vincx, M., Vranken, G. (1985): The ecology of marine nematodes. Oceanography and Marine Biology: An Annual Review 23: 399-489.

[34] Hentschel, B. T., Larson, A. A. (2005): Growth rates of interface-feeding polychaetes: combined effects of flow speed and suspended food concentration. - Marine Ecology Progress Series 293: 119-129. 
[35] Hutchings, P. (1998): Biodiversity and functioning of polychaetes in benthic sediments. Biodiversity and Conservation 7(9): 1133-1145.

[36] Jumars, P. A., Dorgan, K. M., Lindsay, S. M. (2015): Diet of worms emended: an update of Polychaete feeding guilds. - Annual Review of Marine Science 7: 497-520.

[37] Langeneck, J., Busoni, G., Aliani, S., Castelli, A. (2017): Deep-sea polychaetes (Annelida) from the Malta Escarpment (western Ionian Sea). - The European Zoological Journal 84(1): 142-152.

[38] Lindsay, S. M., Woodin, S. A. (1995): Tissue loss induces switching of feeding mode in spionid polychaetes. - Marine Ecology Progress Series 125(1-3): 159-169.

[39] MacDonald, T. A., Burd, B. J., MacDonald, V. I., van Roodselaar, A. (2010): Taxonomic and feeding guild classification for the marine benthic macroinvertebrates of the Strait of Georgia., British Columbia. - Canadian Technical Report of Fisheries and Aquatic Sciences 2874: 1-63.

[40] Mann, K., Lazier, J. R. N. (1991): Dynamics of Marine Ecosystems. Biological Physical Interactions in the Ocean. - Blackwell Scientific Publications, Massachusetts, USA.

[41] Manokaran, S., Khan, S. A., Lyla, S., Raja, S., Ansari, K. G. M. T. (2013): Feeding guild composition of shelf macrobenthic polychaetes of south-east coast of India. - Tropical Zoology 26(3): 120-139.

[42] Mattos, G., Cardoso, R., Dos Santos, A. S. (2012): Environmental effects on the structure of polychaete feeding guilds on the beaches of Sepetiba Bay, south-eastern Brazil. Journal of the Marine Biological Association of the United Kingdom 93(4): 973-980.

[43] Maurer, D., Leathem, W. (1981): Polychaete feeding guilds from Georges Bank, USA. Marine Biology 62(2-3): 161-171.

[44] Méndez, N. (2013): Trophic categories of soft-bottoms epibenthic deep-sea polychaetes from the southeastern Gulf of California (Mexico) in relation with environmental variables. - Pan-American Journal of Aquatic Sciences 8(4): 299-311.

[45] Minelli, A. (1993): Biological Systematics: The State of the Art. - Chapman \& Hall, London.

[46] Misra, R. (1968): Ecology Work Book. - Oxford and IBH Publishing Company, Calcutta, India.

[47] Molua Mwambo, F., Gebregziabher, G., Padeletti, R., Keita, A., Issaka, A., Ioualalen, G., Hinojosa Guzman, B. S., Hegazy, O., Hayyani, A., D’aietti, L., Bayala, R., Azzat, O., Amadou Siako, A. S., Al-areba, A. (2007): Land Evaluation in Essaouira Province Morocco. - Ministry of foreign affairs Istituto Agronomico per L'oltremare, Florence, Italy.

[48] Mosbahi, N., Dauvin, J. C., Neifar, L. (2017): Polychaete fauna from the intertidal zone of the Kneiss Islands (central Mediterranean Sea). - Mediterranean Marine Science 18(2): 215-228.

[49] Muniz, P., Pires, A. M. S. (1999): Trophic structure of polychaetes in the São Sebastião Channel (southeastern Brazil). - Marine Biology 134(3): 517-528.

[50] Okamura, B. (1990): Behavioral Plasticity in the Suspension Feeding of Benthic Animals. - In: Hughs, R. N. (ed.) Behavioral Mechanisms of Food Selection. Springer-Verlag, Berlin, Heidelberg, pp. 637-660.

[51] Pagliosa, P. R. (2005): Another diet of worms: the applicability of polychaete feeding guilds as a useful conceptual framework and biological variable. - Marine Ecology 26: 246-254.

[52] Paiva, P. C. (1994): Trophic structure of a shelf polychaete taxocoenosis in southern Brazil. - Cahiers de Biologie Marine 35: 39-55.

[53] Pinnet, P. R. (2000): Invitation to Oceanography. - Jones and Bartlett Publishers, Sudbury, Massachusetts.

[54] Porras, R., Bataller, J. V., Murgui, E., Torregrosa, M. T. (1996): Trophic structure and community composition of polychaetes inhabiting some Sabellaria alveolata (L.) reefs along the Valencia Gulf coast, western Mediterranean. - Marine Ecology 17(4): 583-602. 
[55] Rodier, J., Legube, B., Merlet, N., Coll, M. (2009): L'analyse de l'eau. - Dunod edition.

[56] Rosenberg, R. (2001): Marine benthic faunal successional stages and related sedimentary activity. - Scientia Marina 65(Suppl. 2): 107-119.

[57] Ruppert, E. E., Barnes, R. D. (1994): Invertebrate Zoology. Sixth Ed. - Saunders College Publishing, Harcourt Brace and Company, Orlando, Florida.

[58] Sanders, H. L. (1958): Benthic studies in Buzzards Bay. I. Animal-sediment relationships. - Limnology and Oceanography III (3): 245-258.

[59] Serrano Samaniego, L. G. (2012): Distribution of soft-bottom polychaetes assemblages at different scales in shallow waters of the northern Mediterranean Spanish coast. - PhD Thesis Doctoral. Universitat Politècnica de Catalunya, Spain.

[60] Simone, C. (2000): Le géosystème Dunaire Anthropisé d'Essaouira-Est (Maroc atlantique): Dynamique et Paléoenvironnements. - PhD Thesis Doctoral, University of Provence Aix-Marseille I, France.

[61] Sivadas, S., Ingole, B., Nanajkar, M. (2010): Benthic polychaetes as good indicators of anthropogenic impact. - Indian Journal of Marine Sciences 39(2): 201-211.

[62] Taurusman, A. A. (2010): Community structure of macrozoobenthic feeding guilds in responses to eutrophication in Jakarta Bay. - Biodiversitas 11(3): 133-138.

[63] Touhami, F., Bazairi, H., Badaoui, B., Bouarour, O., Benhoussa, A. (2017): Merja Zerga lagoon: Study of the functional structure and bioassessment of the ecological quality of benthic communities. - Journal of Materials and Environmental Sciences 8(12): 45914599.

[64] Wang, Y. (2004): Patterns in biodiversity and distribution of benthic polychaeta in the Mississippi canyon, northern Gulf of Mexico. - PhD Thesis Doctoral. Texas A\&M University.

\section{APPENDIX}

Total abundance of polychaete species identified in Essaouira intertidal rocky shores. Data presented has not been standardised to $1 \mathrm{~m}^{-2}$

\begin{tabular}{|c|c|c|c|c|c|c|c|c|c|c|c|c|}
\hline Species & Bh & $\mathbf{Z B}$ & Rg & SEE & QIE & $\mathbf{P t}$ & El & CS & $\mathbf{O u}$ & $\mathbf{T a}$ & SK & If \\
\hline Capitellidae sp & 0 & 0 & 2 & 0 & 0 & 0 & 0 & 0 & 0 & 0 & 0 & 1 \\
\hline Bhawania goodei Webster, 1884 & 1 & 4 & 1 & 4 & 7 & 15 & 0 & 1 & 29 & 113 & 14 & 13 \\
\hline Cirratulidae sp & 0 & 0 & 0 & 0 & 0 & 1 & 0 & 0 & 0 & 3 & 2 & 0 \\
\hline Cirriformia tentaculata (Montagu, 1808) & 0 & 0 & 0 & 0 & 1 & 2 & 0 & 0 & 6 & 2 & 7 & 7 \\
\hline Lysidice ninetta (Audouin \& Milne-Edwards, 1833) & 0 & 2 & 1 & 0 & 0 & 1 & 2 & 0 & 27 & 17 & 4 & 5 \\
\hline Marphysa sp & 0 & 0 & 0 & 0 & 0 & 0 & 0 & 0 & 1 & 0 & 0 & 0 \\
\hline Nematonereis unicornis (Grube, 1840) & 0 & 0 & 0 & 0 & 0 & 1 & 0 & 0 & 0 & 0 & 0 & 0 \\
\hline Scoletoma funchalensis (Kinberg, 1865) & 3 & 0 & 1 & 7 & 5 & 0 & 2 & 4 & 5 & 1 & 2 & 7 \\
\hline Scoletoma impatiens (Claparède, 1868) & 38 & 7 & 12 & 80 & 58 & 16 & 7 & 19 & 13 & 16 & 29 & 69 \\
\hline Lumbrinereis $s p$ & 0 & 0 & 0 & 0 & 0 & 1 & 0 & 0 & 0 & 0 & 0 & 0 \\
\hline Johnstonia clymenoides Quatrefages, 1866 & 2 & 9 & 1 & 6 & 3 & 4 & 7 & 1 & 11 & 3 & 1 & 0 \\
\hline Petaloproctus terricola Quatrefages, 1866 & 0 & 0 & 0 & 0 & 1 & 0 & 0 & 1 & 10 & 0 & 0 & 0 \\
\hline Maldanidae sp & 0 & 0 & 1 & 1 & 0 & 0 & 2 & 3 & 0 & 1 & 0 & 0 \\
\hline Perinereis cultrifera (Grube, 1840) & 22 & 13 & 46 & 12 & 20 & 49 & 16 & 69 & 50 & 43 & 49 & 168 \\
\hline Perinereis marionii (Audouin \& Milne-Edwards 1833) & 11 & 2 & 16 & 0 & 26 & 30 & 0 & 0 & 0 & 0 & 0 & 1 \\
\hline Platynereis dumerilii (Audouin \& Milne-Edwards 1834) & 9 & 57 & 13 & 0 & 33 & 25 & 48 & 3 & 10 & 5 & 49 & 115 \\
\hline Nereis irrorata (Malmgren, 1867) & 0 & 0 & 0 & 0 & 0 & 0 & 2 & 0 & 0 & 0 & 0 & 0 \\
\hline Nereis sp & 0 & 0 & 0 & 3 & 0 & 0 & 0 & 0 & 0 & 0 & 0 & 0 \\
\hline Nereididae sp & 0 & 0 & 2 & 0 & 0 & 1 & 0 & 0 & 0 & 0 & 0 & 0 \\
\hline Scolaricia typica Eisig, 1914 & 0 & 1 & 0 & 0 & 226 & 28 & 0 & 21 & 0 & 0 & 50 & 29 \\
\hline Nainereis laevigata (Grube, 1855) & 4 & 0 & 1 & 0 & 8 & 0 & 0 & 8 & 0 & 0 & 2 & 29 \\
\hline
\end{tabular}




$$
\text { - } 3249 \text { - }
$$

Orbiniidae sp

Eulalia viridis (Linnaeus, 1767)

Mysta picta (Quatrefages, 1866)

Pyhllodoce maculta (Linnaeus, 1767)

Lepidonotus clava (Montagu, 1808)

Polynoidae sp

Sabellaria alveolata (Linnaeus, 1767)

Dasychone lucullana (Delle Chiaje, 1828)

Jasmineira elegans Saint-Joseph, 1894

Spirobranchus triqueter Linnaeus, 1758

Spirorbis sp

Serpula vermicularis Linnaeus, 1767

Serpulidae sp

Nerinides cantabra Rioja, 1919

Polydora ciliata (Johnston, 1838)

Aonides oxycephala (Sars, 1862)

Syllis armillaris Müller, 1776

Syllidae sp1

Syllidae sp2

Terebella lapidaria Linnaeus, 1767

Terebellidae $\mathrm{sp}$

\begin{tabular}{|c|c|c|c|c|c|c|c|c|c|c|c|}
2 & 0 & 0 & 0 & 0 & 0 & 0 & 2 & 5 & 1 & 1 & 0 \\
16 & 2 & 13 & 7 & 16 & 31 & 2 & 9 & 3 & 31 & 25 & 39 \\
0 & 0 & 0 & 0 & 0 & 0 & 0 & 0 & 0 & 0 & 0 & 1 \\
0 & 0 & 0 & 0 & 0 & 0 & 0 & 0 & 0 & 0 & 0 & 4 \\
0 & 2 & 0 & 0 & 0 & 0 & 0 & 0 & 0 & 0 & 23 & 0 \\
0 & 0 & 1 & 3 & 2 & 19 & 1 & 1 & 12 & 21 & 36 & 58 \\
172 & 29 & 81 & 3 & 11 & 264 & 3 & 10 & 22 & 44 & 237 & 199 \\
1 & 0 & 3 & 0 & 0 & 0 & 1 & 1 & 5 & 7 & 9 & 15 \\
7 & 3 & 18 & 4 & 1 & 13 & 2 & 11 & 13 & 40 & 38 & 31 \\
3 & 7 & 43 & 0 & 3 & 7 & 1 & 0 & 11 & 18 & 25 & 18 \\
0 & 0 & 5 & 0 & 0 & 4 & 0 & 0 & 3 & 3 & 0 & 2 \\
0 & 0 & 0 & 0 & 0 & 0 & 0 & 0 & 0 & 4 & 1 & 0 \\
0 & 0 & 0 & 0 & 0 & 3 & 0 & 0 & 0 & 5 & 3 & 2 \\
1 & 0 & 0 & 0 & 0 & 0 & 0 & 0 & 0 & 0 & 0 & 0 \\
0 & 0 & 0 & 0 & 0 & 0 & 0 & 0 & 1 & 0 & 0 & 1 \\
0 & 0 & 0 & 0 & 0 & 0 & 0 & 0 & 18 & 0 & 0 & 2 \\
0 & 0 & 0 & 0 & 0 & 0 & 0 & 0 & 4 & 1 & 0 & 2 \\
4 & 0 & 0 & 0 & 7 & 3 & 1 & 0 & 4 & 4 & 0 & 0 \\
0 & 1 & 0 & 0 & 0 & 0 & 0 & 0 & 4 & 0 & 0 & 16 \\
34 & 2 & 42 & 74 & 16 & 18 & 0 & 15 & 10 & 137 & 20 & 6 \\
1 & 0 & 4 & 4 & 0 & 0 & 0 & 3 & 0 & 0 & 0 & 7 \\
\hline
\end{tabular}

